\title{
Vprašanje sloga v skladbah Jakoba Frančiška Zupana
}

Namen magistrske naloge je bil prikaz izsledkov večstranske raziskave skladateljske ustvarjalnosti Jakoba Frančiška Zupana (1734 - 1810) s ciljem slogovne opredelitve lete. Raziskava je zajela vsa doslej znana, v celoti ali le delno ohranjena skladateljeva dela (šest latinskih in nemških Arij, štiri marijanske antifone, slavospev Egregie Doctor Paule, Stabat Mater, eno orgelsko sonato, Te Deum laudamus, Litanije v G-duru, ter Misso ex C in Mašo v B-duru). Njeno metodološko izhodišče je bila analitična primerjava omenjenih skladb s cerkvenimi deli drugih skladateljev iz druge in tretje tretjine 18. stoletja na podlagi glasbenoteoretskih stališč, ki jih vsebujejo spisi vidnejših teoretikov 18. stoletja, ter učbenik Fundamenta pro Organo, nastal verjetno ob koncu 60. let 18. stoletja na naših tleh in ohranjen v knjižnici frančiškanskega samostana v Novem mestu.

Prvi del naloge obsega dve poglavji. V prvem so poleg že znanih dejstev in kritičnega razmisleka o nekaterih dosedanjih domnevah v zvezi s skladateljevo biografijo povzeti še novi izsledki sistematične raziskave skladateljevega življenja po njegovem prihodu $\mathrm{v}$ Kamnik. Osnovni cilj te raziskave je bila podrobnejša osvetlitev Zupanovega službovanja kot organista, pevovodje in učitelja glasbe v tamkajšnji župnijski cerkvi, ki je skladatelju ne samo odmerjalo obseg pogojev za njegovo poklicno delovanje, npr. vrsto in kakovost izvajalskih možnosti, temveč tudi pomembno vplivalo na njegov "mišljenski slog" in ga zavezovalo k cerkvenoglasbeni tradiciji ali praksi, ki je Zupanove skladbe, podobno kot dela drugih župnijskih mojstrov Srednje Evrope, zaznamovala tudi s cilji rekatolizacije v obdobju 18. stoletja. Gre torej za tiste vsebine, ki zadevajo "konkretno notranjo vez med glasbo in [skladateljevo] biografijo (Eggebrecht) in s tem tudi slogovno podobo njegovih skladb. V drugem poglavju so obravnavani obseg, stopnja in način ohranjenosti Zupanovega skladateljskega dela. Podana je tudi možna razlaga za navzočnost rokopisov njegovih skladb v kar štirih različnih arhivih.

Drugi, osrednji del naloge vsebuje kompozicijsko analizo Zupanovih skladb ter njihovo slogovno primerjavo s cerkvenimi deli skladateljevih sodobnikov. Del obsega štiri 
poglavja: $v$ prvem so obravnavane ritmične, $v$ drugem melodične in oblikovne značilnosti Zupanovih skladb, v tretjem njihova harmonska podoba, v četrtem pa zasedba in skladateljev odnos do vokala in inštrumentala.

Slogovna opredelitev Zupanovih skladb načelno izhaja iz novejšega, strukturalističnega pristopa k zgodovini glasbe, ki se odvrača od (starejše) interpretacije oz. periodizacije lete na način t.i. epohnih slogov in si prizadeva prikazati značilne slogovne poteze posameznih preteklih, relativno samosvojih glasbenokompozicijskih praks predvsem $\mathrm{v}$ povezavi $\mathrm{z}$ njihovo socialno vlogo in mestom ter na sploh nazorskim ozadjem, ki je te značilnosti pogojevalo.

Vsaj nekatere od značilnosti Zupanovih skladb je tako z vidika širšega mišljenskega ozadja mogoče pojasniti kot odsev predvsem ideološko osmišljenih teženj t.i. "nove katoliške kulture (G. Chew) - oziroma z njo povezane "folklorizacije katoliške verske prakse" (M. Germer) -, ki se je tekom druge polovice 17. in še posebej 18. stoletja izoblikovala na območju habsburških in južnonemških dežel, v socialnem okolju podeželskih in malomestnih verskih skupnosti, ter ustvarila posebno cerkvenoglasbeno (kompozicijsko) prakso, ki jo del novejše muzikološke literature slogovno označuje $s$ pojmoma srednjeevropski pastoralni slog (18. stoletja) in stylus rusticanus (B. Macintyre, G. Chew, J. Berkovec). Prva teh značilnosti je vsekakor izrazitejše prevzemanje ritmičnih in melodičnih prvin tedanje, pri preprostejših ljudeh priljubljene plesne glasbe ter - obenem - v osnovi še vedno kvantitativno umevanje ritma in takta na način Schwerpunktstakta, kar je $\mathrm{v}$ Zupanovih skladbah vidno predvsem $\mathrm{v}$ rabi taktovskih mensur kot proporcev (v obeh uglasbitvah mašnega ordinarija), ki jo razkrivajo tudi številne podeželske maše starejših in sodobnih bavarskih mojstrov, ter v izrazito binarni (thesisarsis) zasnovi ritmičnih struktur znotraj-taktnega prostora (predvsem v nastopih zbora in tudi "neplesno" oblikovanih solističnih partij). Razen poudarjene rabe ritmično krepkejših elementov plesa, kakršne vsebuje tudi t.i. "neuradni repertorij" (J. Höfler) približno v istem času nastalih ljudskih katoliških pesmaric nekdanjega avstrijskega območja, je za omenjeno kompozicijsko prakso značilna še močna naslonitev na - relativno samosvoje - srednjeevropsko izročilo ljudskih božičnih pesmi (t.i. Hirtenlied). Zupanove skladbe slednje izkazujejo predvsem v rabi za te pesmi značilnih melodičnih, okrasnih in kadenčnih formul ter tipov uvodne dispozicije melodike (pogosto navzočih tudi v napevih slovenskih katoliških pesmaric 18. stoletja, predvsem Redeskinijeve in Ambrožičeve), kot sta npr. melodična formula s triolo v subdominanti ali pa t.i. osnovni melodični obrazec pastoralnih melodij; pa tudi $\mathrm{v}$ rabi t.i. pastoralnih terc in sekst, $\mathrm{tj}$. $\mathrm{v}$ vzporednem vodenju glasov na razdalji terce ali sekste. Izrazito kratkosapnemu nizanju minucioznih motivičnih prvin, večkrat v obliki iz inštrumentalne glasbe prevzetih melodičnih figur, načelno ustrezata Zupanovo, izvirno za (inštrumentalno) plesno glasbo značilno ritmopoetsko oblikovanje melodij ter sonatna zasnova večine njegovih enostavčnih ter posameznih stavkov večstavčnih skladb. Prav ta, kot rečeno, ideološko motivirana naslonitev na tedanjo plesno glasbo namreč lahko pojasni dokaj pogosto in $\mathrm{v}$ primerjavi z drugo cerkveno glasbo tega časa tudi skorajda izjemno navzočnost sonatno oblikovanih stavkov v poljudnejših in pozneje tudi "manj poljudnih" uglasbitvah religioznih besedil iz sredine in druge polovice 18. stoletja, nastalih na območju sreednjeevropskega kulturnega prostora. Razen sočasnim suitnim stavkom podobnih oblikovnih rešitev velja kot temeljno 
lastnost Zupanovega oblikovnega mišljenja poudariti predvsem njegovo v osnovi še vedno retorično umevanje formalne gradnje stavka oziroma izrazito kadenčno koncipirano oblikovanje - bodisi sonatnih, rondojskih, pesemskih ali pa zgolj multisekcijskih stavkov.

Od zanimivejših potez harmonske zgradbe Zupanovih skladb velja omeniti predvsem skladateljevo pogosto rabo nepripravljenih - v generalnem basu označenih disonantnih akordskih intervalov, ki jo sočasna teoretska literatura (npr. Marpurga, C. P. E. Bacha, Kirnbergerja in Türka) razlaga kot značilnost "galantnega načina komponiranja", sukcesivna in tudi simultana prečja ter še posebej v generalnem basu neoznačene, a skupaj z njim nastopajoče "dodane disonance", skoraj izključno k sozvočjem z dominantno funkcijo, kar spominja na znano Rameaujevo koncepcijo o "funkcionalni vlogi disonancu. Vendar pa so takšne disonance v Zupanovem stavku, ki kaže generalbasovko dojemanje vertikale, bržkone le posledica konsistentno izpeljanih figuracij posameznih glasov in jih je zato mogoče skladno $\mathrm{z}$ Marpurgovo teorijo prisoditi med t.i. "stranske note", ki so tedaj sodile bolj v okvir melodične kot pa harmonske prvine glasbenega stavka (J. Lester), ter pojasniti kot odraz posebnega okusa in z njim povezanih "nenapisanih manir"-geografsko in socialno profiliranega - stila rusticanus (G. Chew).

Prav dopadljivi, poudarjeno plesni značaj in grobo zveneča disonantnost pastorellam podobnih cerkvenih skladb sta ob koncu 18. in v začetku 19. stoletja postala tarča kritike vse bolj "italijaniziranega glasbenega okusa" tudi v podeželjskem in malomestnem okolju Srednje Evrope (G. Chew); ter na drugi strani argument v prizadevanju cerkvenih oblasti za postopno odstranitev tovrstne glasbe in zlasti t.i. "godčevstva" $\mathrm{Z}$ župnijskih korov tega območja (J. Höfler). Sodelovanje ljudskih godcev v podeželjskih in malomestnih cerkvah Srednje Evrope pa je bržkone tudi odločilno vplivalo - manj na sestavo kot - na obravnavo inštrumentala sočasne produkcije poklicnih glasbenikov v njih. Gre za skoraj dosledno colla parte rabo dveh godal, ki jo tudi Zupan v svojih skladbah le redko pomembneje "preseže ". Trio zasedbi dveh violin in orgel kot generalnim basom $\mathrm{v}$ tem pogledu izjemen je le uvod k Stabat Mater, z izpisanim partom "koncertantnih orgel" v tipično "avstrijski rokokojski maniri (E. Olleson) - se v štirih Zupanovih skladbah pridružujeta še dva rogova, $v$ treh pa par klarinov, zvečine le v vlogi dinamične krepitve akordskih tonov.

Vendar pa tovrstna razširitev in popestritev spremljave pri izvajanju Zupanovih skladb, kot potrjuje že skladateljev pripis v trobilnem separatu Himnusa in D, ki v primeru pomanjkanja ustreznih glasbenikov predlaga nadomestitev obeh rogov z violinama, tedaj pri nas ni bila vselej mogoča. To seveda na svoj način, a dovolj zgovorno razodeva skromnejše ustvarjalne možnosti in pogoje, v katerih je omenjena produkcija župnijskih glasbenikov Srednje Evrope nastala, in katere vidnejši del so tudi ohranjena cerkvena dela Jakoba Frančiška Zupana.

Obranjeno 2. marca 2000 na Filozofski fakulteti Univerze v Ljubljani. 
MUZIKOLOŠKI ZBORNIK • MUSICOLOGICAL ANNUAL XXXVI

\section{A Question of Style in the Compositions ofJakob Frančišek Zupan}

The intention of the present $M . A$. work was to present the results of a multifaceted investigation of the compositional creativity of Jakob Frančišek Zupan (17341810) with the goal of defining its style. The research involved all of his known works in their entirety or partially as they may be preserved (six Latin and German Arias, four Marian antiphons, the hymn Egregie Doctor Paule, Stabat Mater, one organ sonata, Te Deum laudamus, the Litany in G Major, Missa ex C and the Mass in B Minor). The methodological starting point was an analytical comparison of the mentioned works with the church works of other composers from the last two-thirds of the $18^{\text {th }}$ century; the basis of the comparison involved theoretical viewpoints from the more known theoretical writings of the $18^{\text {th }}$ century and the textbook Fundamenta pro Organo, which was most likely written at the end of the $60^{\text {th }}$ year of the $18^{\text {th }}$ century in Slovenia and is kept at the Franciscan Monastery Library in Novo mesto.

The first part of the present work contains two chapters. In the first chapter, besides the already known facts and critical reflections about some of the previous suppositions regarding the composer's biography, there are new results of a systematic research of the composer's life after his arrival in Kamnik. The primary goal of this research was a more detailed exposure of Zupan's employment as an organist, choirmaster and music teacher at the main church in Kamnik, which not only determined the composer's professional work, i. e. the type and nature of his performance possibilities, but also significantly influenced his "way of thinking" and tied him to church music traditions or practices which were similar to the work of other parish masters of Middle Europe and rooted in the goals of the re-Catholicizing during the $18^{\text {th }}$ century. Thus this chapter concerns itself with the "concrete internal connection between music and [the composer's] biography" (Eggebrecht) along with the stylistic image of his compositions. In the second chapter are discussions of the extent, degree and method of preserving Zupan's compositional works; also discussed is a possible explanation for the presence of hand-written copies of his compositions in four different archives.

This account then continues with an analysis of Zupan's compositions and their stylistic comparison with church works of contemporaneous composers. This part extends for four chapters: in the first are discussions of rhythmic and in the second, melodic and formal characteristics of Zupan's compositions; in the third his harmonic portrait is discussed and in the fourth, his instrumentation and relationship with the vocal and instrumental.

The stylistic definition of Zupan's compositions principally resulted from the application of the more recent structuralist approach to music history, which diverts away from the (older) interpretation or periodizing of music according to the style of the epoch and endeavors to demonstrate the characteristic stylistic features of individual, bygone, and relatively independent compositional practices primarily in connection with their social role and position as well as in relation to the ideological background which conditioned the characteristics. 
It is possible to elucidate at least something of the characteristics of Zupan's compositions from a broad point of view which above all reflects the ultimate end of the ideological aspiration of the "new Catholic culture" (G. Chew) with its associated "folklorizing of the practice of the Catholic faith" (M. Germer) which began in the second half of the $17^{\text {th }}$ century and strengthened throughout the $18^{\text {th }}$ century within the social milieu of rural and village religious groups in the region of the Habsburg and Southern German provinces, and which created a special church music (compositional) practice whose style has been designated in contemporary musicological literature as Middle European pastoral style ( $18^{\text {th }}$ century) and rustic style (B. Macintyre, $G$. Chew, J. Berkovec). The first of these characteristics is by all means a more distinctive use of rhythmic and melodic elements as were used at that time in the more simple popular folk dance music while, simultaneously, a quantitative understanding of rhythm and measure in accord with Schwerpunktstakt remaining at the foundation - this being most discernible by his use of the mensur as proportions (in both settings of the ordinary of the mass), which the numerous provincial masses of older and contemporaneous Bavarian masters also reveal, and by his use of binary (thesisarsis) forms of rhythmic structures in the "within-measure" space (above all at the entrance of the choir and also the "non-dance" solo sections). Besides the emphasised use of the rhythmically stronger elements of dance as was also contained in the "unofficial repertoire" (J. Höfler), i.e. the Catholic folk hymnals of the earlier Austrian region from Zupan's time, there was a characteristically strong leaning on the relatively independent Middle European tradition of the Christmas folk song (Hirtenlied). Zupan's compositions demonstrate the latter primarily in characteristic melodic, ornamental and cadential formulas, and certain types of introductory arrangements of melodics (also frequently present in the Slovenian Catholic Melody hymnals of the $18^{\text {th }}$ century, especially those of Redeskini and Ambrožič) such as melodic formulas with triplets in the subdominant, the so-called basic melodic form of pastoral melodies, and his use of the "pastoral" thirds and sixths. In his arranging of minute motivic elements, often borrowed from instrumental music, Zupan's works fundamentally correspond to a rhythmic shaping of melodies originally present in (instrumental) dance music as well as to the sonata form, which he employed in most of his single movements and the individual movements of his multi-movement works. As has just been indicated, the ideologically motivated leaning on dance music at that time can explain the very frequent and, in comparison with other church music of this time, also almost exceptional presence of the sonata form movement in popular and later also less popular settings of religious texts from the middle and later half of the $18^{\text {th }}$ century in Middle European culture. He employed a similar formal solution for his suite movements. Another fundamental characteristic of Zupan's thinking on form is his basically rhetorical understanding of the formal structuring of a composition or a clearly cadentially based form, either sonata, rondo, song or merely multisectional movements.

Of the more interesting features of the harmonic organisation of Zupan's compositions, it is above all worth mentioning the composer's frequent use of unprepared dissonant chordal intervals (indicated in the figured bass), which contemporaneous 
theoretical literature (for example Marpurg, C. P. E. Bach, Kirnberger and Türk) refered to as a characteristic of the "galant style of composing "; we must also note his use of successive and also simultaneous cross relations and his "supplemental dissonances" which are not marked in the figured bass and which are almost exclusive to dominant function harmonies as is reminiscent of Rameau's concept of the "functional role of dissonance". However, Zupan's characteristic use of dissonance is most likely only the result of the consistency of his melodic logic; therefore, congruent with Marpurg's theory, it is possibly to view them as "subordinate notes", which at that time were better considered in the context of a melodic rather than a harmonic element of compositional technique (J. Lester), and to explain them as reflecting a particular taste and with this the connected geographically and socially profiled "unwritten manner" of stilus rusticanus ( $G$. Chew).

It is just these pleasant and obviously dance-like characteristics as well as the coarse dissonance of church compositions similar to pastorelle that became the target of criticism of the increasingly "Italianised musical taste " at the end of the $18^{\text {th }}$ and beginning of the $19^{\text {th }}$ centuries, even in the provincial and village environments of Middle Europe (G. Chew); as well as the focus of argument in the endeavour of church authorities to gradually eliminate this type of music, especially the so-called "fiddlers music " of the parish choirs of this period (J. Höfler). Most likely the collaboration of folk fiddlers in the provincial and village churches of Middle Europe also decidedly influenced - less the structure as - the treatment of the contemporaneous instrumental output of professional musicians in these areas. Regarding this, one finds an almost consistent colla parte use of two string instruments, which Zupan's compositions only rarely significantly exceed. In the trio instrumentation for two violins and organ as figured bass - an exception being only the introduction to the Stabat Mater where the parts are written out for the "concertante organ" in the typical "Austrian hand-written" manner (E. Olleson) - two horns were added in four of Zupan's compositions, and a pair of clarinets, in three works, the majority of the additions being only in the role of a dynamic strengthening of the chordal tones.

However, this type of expanded and variegated accompaniment in the performance of Zupan's compositions, as confirmed by the composer's postscript in the wind instruments' part of the Himnus in $\mathrm{D}$ where he proposes the substitution of violins for both horns in case of a deficiency of adequate musicians, was not always possible at that time. This of course is in accord with one's personal manner, but enough is clear about the humble creative possibilities and conditions in which the mentioned output of the parish musicians of Middle Europe arose, the more important example being the preserved church music of Jakob Frančišek Zupan.

Defended on March 3, 2000, Philosophical Faculty, University of Ljubljana. 